gia. Destaca a defasagem das leis federais que envolvem a preservação de sítios arqueológicos, bem como a ausência de profissionais capacitados para promover um eficaz planejamento turístico em torno de elementos arqueológicos. Ressalta, ainda, a importância da contribuição acadêmica dos profissionais em arqueologia nos processos de planejamento turístico.

Em linhas gerais, pode-se dizer que a obra é uma interessante contribuição para os que intentam iniciar uma maior compreensão sobre o fenômeno do turismo em seus diversos aspectos, principalmente sob a égide da questão cultural.

No entanto, alguns pontos podem ser observados no decorrer da leitura. Primeiramente, verifica-se que nenhum dos autores possui formação em turismo. Tal fato pode explicar a ausência de um maior aprofundamento sobre as relaçōes existentes entre cultura e turismo em alguns capítulos. Por outro lado, algumas bibliografias apresentadas no final de cada capítulo apresentam-se incompletas, dificultando a atividade de pesquisa. Algumas afirmaçōes categóricas estabelecidas por alguns autores também não exprimem suas fontes, seja nos rodapés ou na bibliografia. Por essa razão, acredita-se que a presente obra tenha sido idealizada para satisfazer principalmente a uma parcela iniciante em estudos sobre turismo.

De qualquer forma, a diversificação de assuntos e a abordagem sob várias óticas de pensamento trazem um especial valor à referida obra. Por isso, recomendamos a sua leitura.

Marcela Ferraz Candioto

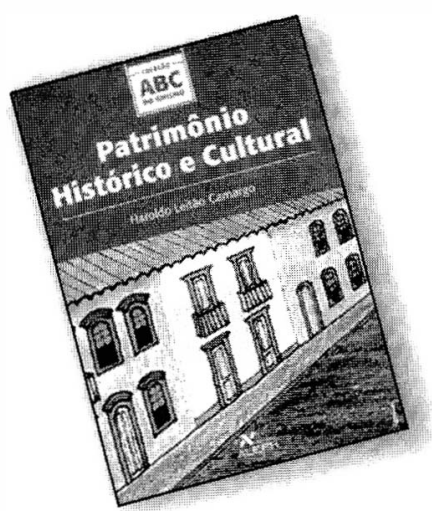

CAMARG0, Haroldo Leitão. 2002

\section{Patrimônio histórico e cultural}

São Paulo: Aleph. 104 p.

Haroldo Leitão Camargo é historiador e doutor em História Social pela Faculdade de Filosofia, Letras e Ciências Humanas da USP. Escreveu sobre Fundamentos Multidisciplinares do Turismo: História, no livro Turismo: como aprender, como ensinar, v. 1, Editora Senac. Professor de Pós-Graduação das disciplinas Patrimônio e Turismo e História do Turismo, coordenador dos cursos de Turismo, Administração e Administração Hoteleira e professor de História da Cultura e do Brasil no Unibero - SP, no período de 1974 a 2002.

Esta obra faz parte da coleção $\mathrm{ABC}$ do Turismo, da editora Aleph, uma proposta de apresentar de forma objetiva e sucinta vários temas da atividade turística. $\mathrm{O}$ título em análise é apresentado em três partes divididas em subtemas.
O autor, na primeira parte, trata da questão do patrimônio, o seu significado e os motivos da sua destruição e preservação. Faz um relato histórico que mostra não ser um problema atual a não-preservação dos bens materiais, uma vez que até o final do século XVIII não havia esta preocupação. A destruição dos monumentos se dava, principalmente, por motivos ideológicos. Com o advento da sociedade industrial, caracterizada pela necessidade de lazer e turismo, outras questōes levam à destruição. Desta vez o valor material do terreno se sobrepōe ao do bem histórico, como imposição da especulação imobiliária. Conclui mostrando que o vandalismo já existia há 200 anos, sendo que as primeiras preocupações com a preservação vão surgir no final do século XVIII, período em que são criados os primeiros museus, na concepção atualizada da palavra.

Em sua segunda parte, a obra trabalha o patrimônio a partir do seu uso econômico, que fez gerar os serviços de alimentação e hospedagem, traçando uma linha do tempo a partir do Grand Tour (viagens com mais de dois anos), e vai delinear práticas de turismo que serão usadas no futuro. Na segunda metade do século XVIII começa a desaparecer o sentido cultural das viagens, e os objetivos de cura se sobressaem para chegar às viagens em busca do prazer mundano. A descoberta de novos lugares pela burguesia é um prenúncio do turismo de massa, que conta com os meios de comunicação para sua propagação. Finaliza com a consolidação do turismo no final do século XIX, sendo o patrimônio um forte apelo para as viagens com o aumento das facilidades de deslocamento, como o navio a vapor e as ferrovias. Neste contexto histórico, o surgimento do guia de turismo valoriza o patrimônio e faz a oferta mais acessível para outras camadas sociais.

Na terceira e última parte é traçada uma trajetória do desenvolvimento das cidades brasileiras, especificamente São Paulo e Rio de Janeiro - esta última transformada na capital da monarquia e do império português -, e dos serviços oferecidos pelos imigrantes, mostrando a destruição do patrimônio do Brasil Colônia como consequiência da idéia de progresso trazida da Europa. Seguindo uma mesma didática, faz um relato do processo de consolidação, reconhecimento e necessidade de preservação do patrimônio cultural brasileiro, envolvido por questōes políticas desde a década de 1930, quando é criado o IPHAN. Analisa a noção de patrimônio do Brasil por diferentes caminhos em relação à Europa. Toma como exemplo a cidade de Ouro Preto, que desde a década de 1920 foi motivo de preocupação preservacionista pelos modernistas.

Apesar de tratar da relação do patrimônio com o turismo através da história, o texto é elucidativo para quem deseja conhecer as origens do patrimônio do Brasil, a partir do período colonial até chegarmos ao século XIX, quando o turismo se reafirma mundialmente como fenômeno social e econômico para, a partir da década de 1930, tomar outra dimensão, quando é visto com preocupaçōes preservacionistas. Para melhor compreensão, uma nova conceituação e abrangência do patrimônio são relatadas no final, acompanhadas de indicaçōes comentadas para leitura.

O livro de 104 páginas é uma valiosa contribuição para o entendimento das questōes patrimoniais brasileiras. Apesar da linguagem histórica, sua proposta é fazer esta relação com o turismo, não de forma técnica, porém, aponta caminhos para este fim. Portanto, é perfeitamente recomendável, especialmente para aqueles interessados na área do patrimônio e do turismo cultural. 